\title{
Design of Motorcycle Security System Using Fsr (Force Sensitive Resistor) Sensor, Arduino Uno Microcontroller and Sim800L Module
}

\author{
Fitriyanto Andy Pratama , Frida Agung Rakhmadi \\ Physics Department, Faculty of Science and Technology, UIN Sunan Kalijaga \\ Jl. Marsda Adisucipto No 1 Yogyakarta 55281, Indonesia. Tel. +62-274-540971, Fax. +62-274-519739 \\ *Email: Fitriyantoandyp@gmail.com
}

\begin{abstract}
The background of this research was the crime of rampant cases seizure and motorcycle theft. The aims of this research were to characterize FSR sensor, to make and test of motorcycle security system using FSR sensor, arduino uno microcontroller and SIM800L module. This research was done through five stages: sensor characterization, software development, hardware manufacture, system testing and data processing. The results of this research showed that FSR sensor has characterization of transfer function $\mathrm{V}=1.29+0.04 \mathrm{M}$ with $\mathrm{r}=0.99$ and repeatability equal to $99.34 \%$. In addition, FSR sensor can detect human by ranging from $27.8 \mathrm{~kg}$ to $82.3 \mathrm{~kg}$ which is equivalent with voltage 2.55 volt to 4.55 volt. Meanwhile, the success rate of motorcycle security system in the process of sending notification was $98 \%$ and the success rate of system in taking command to turn on and turn off the motorcycle security system were $97 \%$ and $98 \%$.
\end{abstract}

Keywords: Arduino uno microcontroller, FSR censor, Security system, SIM800L module

\section{INTRODUCTION}

The Indonesian economy is currently still hit by uncertainty, one of which is the impact of still not optimal improvements in the world economy (Bratadharma, 2016). The economy that is still unstable has a negative impact on society. The negative impacts that occur are, increasing unemployment and poverty rates. The impact of the impact of the economy is one of the factors causing the rise of crime cases (Antara, 2015).

Spoliation is a crime carried out on the road by robbing or stealing a motorbike that can cause mental and life losses (Monika, 2015). Crime is an unsettling act. Therefore, it is necessary to take action to reduce and prevent acts of crime. One way to reduce and prevent crime, especially the crime of seizing motorbikes is by providing security on motorbikes.

The current security or alarm system that is often found in the field is a conventional alarm that only sounds when the motorcycle is shaken. This incident can be known by motorcycle owners directly, but there has been no specific notification to motorcycle owners if the motorcycle owner is far from the reach of a motorcycle.

Based on these problems, it is necessary to make a motorcycle safety system with special notification to motorcycle owners. The system will provide information to motorcycle owners in the form of SMS (Short Message Service) that works when the motorcycle is in a parking condition. In addition SMS is also used by motorcycle owners to give orders to turn off and turn on the system found on motorbikes. Later it can be used when a motorcycle is being driven and there is a hitching.

\section{MATERIALS AND METHODS}

\section{Characterization of FSR Sensor}

Characterization of FSR sensor includes transfer function and their input-output relationship, repeatability, and accuracy.

\section{Manufacturing of Detection System}

Manufacture of motorcycle safety system based on Figure 1 and 2.

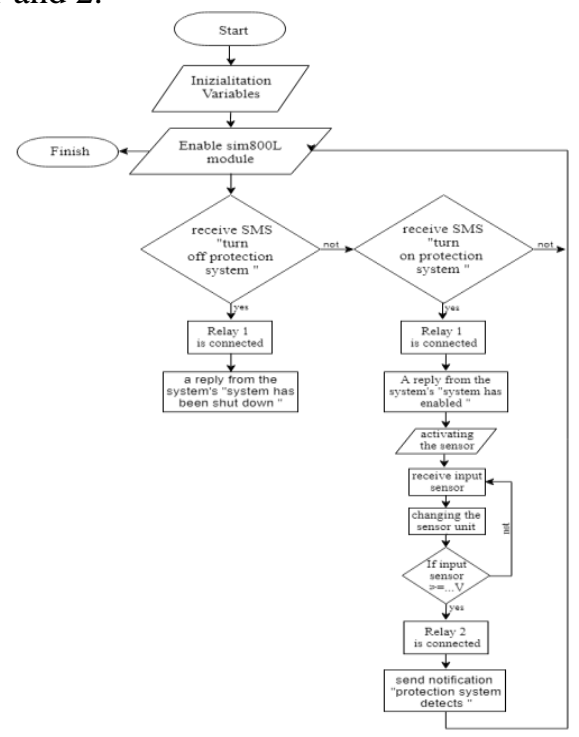

Figure 1. Flowchart software system of motorcycle safety. 


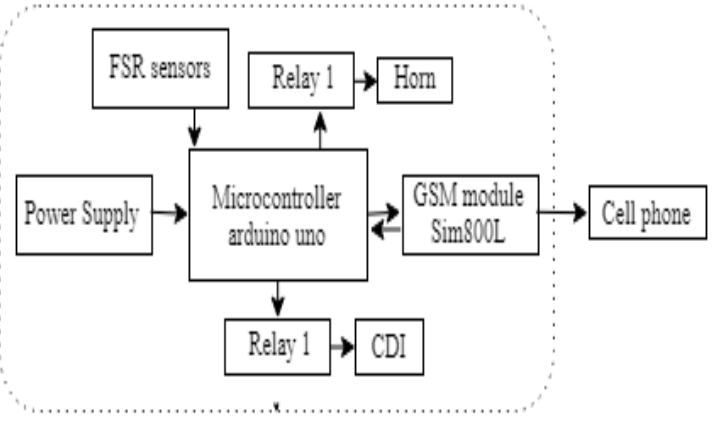

Figure 2. Block diagram-making system hardware.

After the making of the motorcycle safety system has been completed, the next step is testing the system. System testing is performed on two conditions, namely, the State of the place is less than $1 \mathrm{~km}$ and circumstances elsewhere have the distance of $\pm 1.4 \mathrm{KM}$. The first testing is successful or not sensors detect and send notifications. Further testing is whether the system successfully received orders turn on and turn off the safety systems. Taking data from the testing done by giving the sign's " $\checkmark$ " if it works and gives the sign " $\boldsymbol{x}$ " if it doesn't work. The data is then done processing to knowing how big the success rate of the system that. Furthermore, the test results are calculated percentage of success with the following formula.

The success rate of the system $=\frac{\sum \text { successfully }}{\sum \text { experiment data }} \times 100 \%$

\section{RESULTS AND DISCUSSION}

\section{Characterization of FSR Sensor}

The result of characterization of FSR sensor in this research showed transfer function of FSR sensor was $\mathrm{V}$ $=1.29+0.04 \mathrm{M}$ and its input-output relationship was very strong with correlation coefficient $\mathrm{r}=0.99$; sensor repeatability was $99.3 \%$; and minimum limit of FSR sensor detection $2.55 \mathrm{~V}$ obtained from the masses 27.8 $\mathrm{Kg}$.

\section{Manufacture of Motorcycle Security System}

Motorcycle safety system uses sensors FSR (Force Sensitive Resistor), arduino uno microcontroller and module SIM800L indicated by Figure 3 and the display results on the application message are shown by Figure 4.

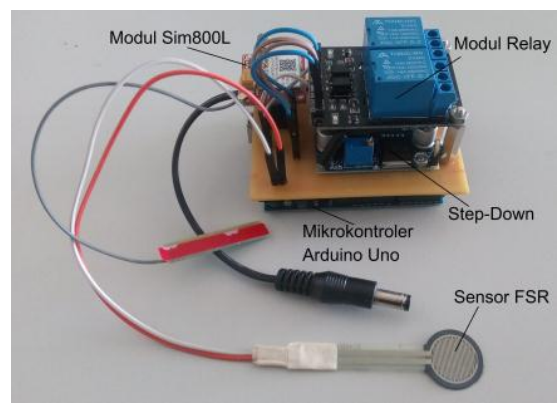

Figure 3. The results of the creation of a security system motorcycle.

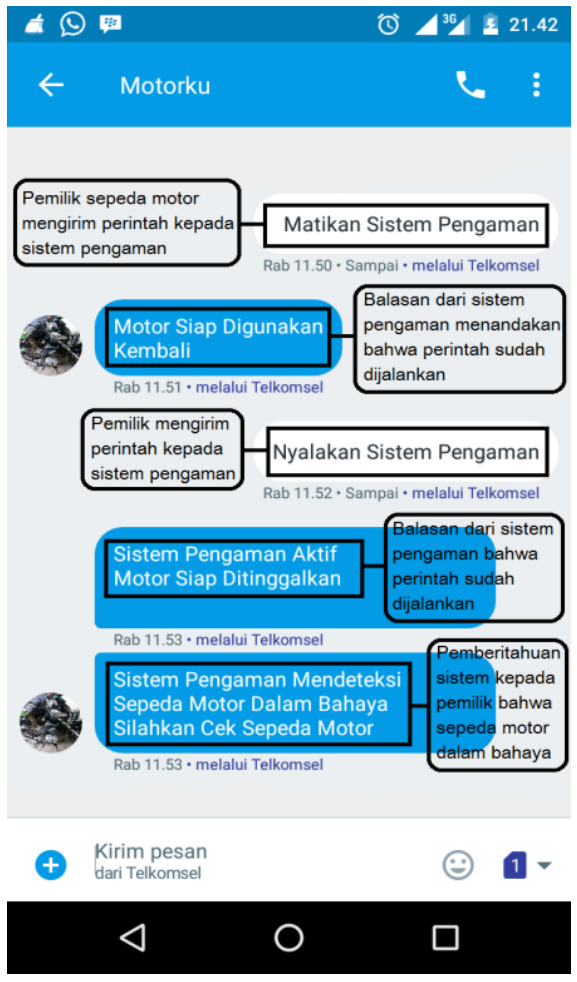

Figure 4. Display application message.

When the power supply is connected with the safety system, the system is ready to accept a command message with format language "turn on the security system" to turn on the safety system and turn off the motorcycle electrical system. The format of the language's "turn on the security system" is also used to enable detection system. In addition, the system can accept the command message with format "turn off the security system" to turn off the security system.

The security system can give a reply when the command has been executed by the system, that is in the form of a reply message with the language format "active safety system" and "the motorcycle is ready" indicates that the security system has finished executing the command to turn on the security system. In addition, the system can also provide notification when the detection system detects an object, that is the system sends a message in the form of a message to the user with the format "the system detects, the motorcycle is in danger, please check the motorcycle".

FSR sensor used in this study serves as a detection system. The working principle of the FSR sensor is by pressing on the sensor area. This sensor works according to the amount of pressure applied to the sensor area, so that the more pressure the more active element points touch the semiconductor layer.

\section{Testing System of Motorcycle Safety}

The success rate of the system sends notifications and receives orders in the condition of in the place and also in the condition in the field with distance $\pm 1.4 \mathrm{KM}$ from the user is shown in Table 1. 
Table 1. Testing system of motorcycle safety on condition in the place and in the condition of the field with a distance of $\pm 1,4 \mathrm{KM}$ from the user.

\begin{tabular}{lll}
\hline $\begin{array}{l}\text { System Success } \\
\text { Rate }\end{array}$ & $\begin{array}{l}\text { Condition Results } \\
\text { in Place }\end{array}$ & $\begin{array}{l}\text { Results of Conditions } \\
\text { in the Field }\end{array}$ \\
\hline $\begin{array}{l}\text { The system sends } \\
\text { notifications }\end{array}$ & $98 \%$ & $100 \%$ \\
$\begin{array}{l}\text { Receive an order to } \\
\text { turn on the security }\end{array}$ & $97 \%$ & $100 \%$ \\
system & \\
$\begin{array}{l}\text { Receive an order to } \\
\text { turn off the security } \\
\text { system }\end{array}$ & $98 \%$ & $100 \%$ \\
\hline
\end{tabular}

Motorcycle safety system testing has a level of success of the system to send notifications and receive orders in place or in the field with a distance of $\pm 1.4 \mathrm{KM}$. The system success rate of sending notifications is $98 \%$ and $100 \%$, and the success rate of the system receives commands turning on the system $97 \%$ and $100 \%$. While the success rate of the system receives an order to shut down the security system, it is $98 \%$ and $100 \%$. The success rate after being taken on average has met $97 \%$ National standards (Suryono, 2012).

Although the success rate has exceeded international minimum standards, the success rate of motorcycle safety systems has not reached $100 \%$. This is presumably because the test is affected by a provide signal that is less stable at the test location. So that some tests failed to convey user orders to the motorcycle safety system.

\section{CONCLUSIONS}

FSR sensor in this research showed transfer function of FSR sensor with input-output was correlated with coefficient $r=0.99$, sensor repeatability minimum limit of FSR sensor detection $2.55 \mathrm{~V}$ from the masses 27.8 $\mathrm{Kg}$.

FSR sensor used in this study serves as a detection system. The sensor works according to the amount of pressure applied to the sensor area, so that the more pressure the more active element points touch the semiconductor layer.

The system sends notifications and receives orders in the condition in the field with distance $\pm 1.4 \mathrm{KM}$ from user. The system success rate of sending notifications is $98 \%$ and $100 \%$, and the success rate of the system receives commands turning on the system $97 \%$ and $100 \%$. The success rate after being taken on average has met $97 \%$ National standards.

\section{REFERENCES}

Antara. 2015. Faktor Ekonomi Ditenggarai Jadi Penyebab Maraknya Begal. Accessed on April 19, 2017 from www.kabar24.bisnis.com.

Bratadharma, Angga. 2016. Merekam Perkembangan Ekonomi Indonesia Sampai Maret 2016. Accessed on April 19, 2017 from www.ekonomi.metrotvnews.com

Monika. 2015. Upaya Kepolisian Dalam Menanggulangi Tindak Pidana Pembegalan Di Wilayah Kota Yogyakarta. Program Studi Ilmu Hukum, Fakultas Hukum, Universitas Atmajaya Yogyakarta

Suryono. 2012. Worksop Peningkatan Mutu Penelitian Dosen dan Mahasiswa. Yogyakarta: Program Studi Fisika UIN SUKA. 
THIIS PAGE INTENTIONALLY LEFT BLANK 